\title{
Challenging Gender Discrimination in Closely HELD FiRMS: THE HOPE AND HAZARD OF CORPORATE OPPRESSION DOCTRINE
}

\author{
MEREDITH R. MILLER*
}

The \#MeToo Movement has ushered sexual harassment out of the shadows and "has shifted social attitudes, inspired widespread calls for change and resulted in unprecedented accountability." "The Movement has also "thrown a glaring spotlight on the gender gap in the workplace." Nevertheless, "the revelations about the pervasiveness of harassment - and of the legal and institutional failures to address it - illuminate how tough it will be to extinguish." ${ }^{33}$ This has been true for all workers, including partners ${ }^{4}$ - those women who are owners in their firms and claim that they have suffered harassment or unfair treatment based on gender.

There has been a steady, growing stream of cases filed by female partners against their law firms, claiming unfair treatment and sexual harassment. ${ }^{5}$ This

* Professor of Law, Jacob D. Fuchsberg Law Center, Touro College; principal, Miller Law, PLLC. Thank you to Touro Law student Joseph Rossello for exceptional research assistance.

1. Jodi Kantor, \#MeToo Called for an Overhaul. Are Workplaces Really Changing?, N.Y. Times (Mar. 23, 2018), https://www.nytimes.com/2018/03/23/us/sexual-harassment-workplaceresponse.html [https://perma.cc/3QMN-7S9Y].

2. Vanessa Fuhrmans, What \#MeToo Has to Do with the Workplace Gender Gap, WALL ST. J., Oct. 23, 2018, at R1.

3. Kantor, supra note 1.

4. In some instances, this Article uses the term "partner" colloquially to describe an owner of a business, even if the business is not technically organized as a partnership but is, for example, a corporation or limited liability company. It also uses the term "owner" or "investor" to mean the same thing.

5. See Campbell v. Chadbourne \& Parke LLP, No. 16-CV-6832 (JPO), 2017 WL 2589389 (S.D.N.Y. June 14, 2017); Miller v. Levi \& Korsinsky, LLP, No. 1:20-cv-01390 (S.D.N.Y. filed Feb. 18, 2020); Jack Newsham, Ex-Partner of Plaintiffs Securities Firm Alleges Gender Discrimination in New Suit, N.Y. L.J. (Feb. 18, 2020), https://www.law.com/newyorklawjournal/ 2020/02/18/ex-partner-of-plaintiffs-securities-firm-alleges-gender-discrimination-in-new-suit/ [https://perma.cc/UJK6-TSK7]; Knepper v. Ogletree, Deakins, Nash, Smoak \& Stewart, P.C., No. 2:19-cv-00527-JVS-ADS, 2019 WL 1449502 (C.D. Cal. Mar. 26, 2019); Debra Cassens Weiss, Gender Bias Plaintiff Takes New Tack with State Court Complaint, ABA J. (Jan. 30, 2019, 12:06 PM), https://www.abajournal.com/news/article/gender-bias-plaintiff-takes-new-tack-with-statecourt-complaint [https://perma.cc/K3SB-34A5]; Ramos v. Super. Ct., 239 Cal. Rptr. 3d 679 (Ct. App. 2018), modified, No. A153390, 2018 Cal. App. LEXIS 1090 (Ct. App. Nov. 28, 2018), rev. denied, No. S253014, 2019 Cal. LEXIS 981, cert. denied sub nom. Winston \& Strawn LLP v. Ramos, 140 S. Ct. 108 (2019); Ribeiro v. Sedgwick LLP, No. C 16-04507 WHA, 2016 WL 6473238 (N.D. Cal. Nov. 2, 2016); Bertram v. Proskauer Rose LLP, No. 17mc207 (DLC), 2018 WL 3559092 (S.D.N.Y. July 24, 2018); Stephanie Francis Ward, Amended Complaint Naming Plaintiff Filed in Proskauer Gender Discrimination Case, ABA J. (Apr. 26, 2018, 2:35 PM), https://www.abajournal.com/news/article/amended_complaint_naming_plaintiff_filed_in_ proskauer_gender_discrimination [https://perma.cc/9SWB-WZRU]; Kirleis v. Dickie, McCamey \& Chicolte, PC, No. 06-1495, 2007 WL 2142397 (W.D. Pa. July 24, 2007); Panepucci v. Honigman 
is not surprising in light of a recent survey finding that female law partners face a 53\% gap in pay at top United States law firms. ${ }^{6}$ Similarly, there is no shortage of cases where female partners in medical practices, accounting, and finance firms have alleged harassment or unfair treatment. ${ }^{7}$ There has even been at least one lawsuit filed by a male law firm partner claiming retaliation for speaking out against sexual harassment at the firm. ${ }^{8}$ There are likely many similar claims that have just never been filed. ${ }^{9}$ That is because all of these lawsuits suffer a similar, often insurmountable hurdle: plaintiff's status as a partner in the firm means that they may not be considered an "employee" under the relevant employment discrimination statutes. ${ }^{10}$ There is an underexplored and underutilized potential alternative in seeking a remedy: oppression (or "freeze out") doctrine in the closely held business. This Article explores corporate oppression doctrine as a potentially viable alternative for partners to combat gender discrimination and harassment. ${ }^{11}$

Diane Straka's story is illuminating and appears to be the first reported case to discuss shareholder oppression through a gender-based lens. ${ }^{12}$ With three male founders, Straka, an experienced certified public accountant, merged two separate

Miller Schwartz Cohn, LLP, 408 F. Supp. 2d 374 (E.D. Mich. 2005).

6. Elizabeth Olson, Female Law Partners Face 53 Percent Pay Gap, Survey Finds, BLOOMBERG L. (Dec. 6, 2018, 9:02 AM), https://news.bloomberglaw.com/business-and-practice/ female-law-partners-face-53-percent-pay-gap-survey-finds [https://perma.cc/CEY4-9VMY].

7. See, e.g., Baskett v. Autonomous Research LLP, No. 17-CV-9237 (VSB), 2018 WL 4757962 (S.D.N.Y. Sept. 28, 2018) (finance); Kassman v. KPMG LLP, 925 F. Supp. 2d 453 (S.D.N.Y. 2013) (accounting); Pinter-Brown v. Regents of Univ. of Cal., 261 Cal. Rptr. 3d 486 (Ct. App. 2020) (doctor-owner).

8. Solon v. Kaplan, 398 F.3d 629 (7th Cir. 2005).

9. The cases are also underreported because many are subject to private and confidential resolution in arbitration, given that many partnership agreements contain arbitration clauses.

10. Erin Mulvaney, Law Firm Bias Cases Hinge on Meaning of Partner, Bloomberg L. (Apr. 26, 2019, 6:16 AM), https://news.bloomberglaw.com/daily-labor-report/law-firm-bias-caseshinge-on-meaning-of-partner [https://perma.cc/CT8A-53MN].

11. The focus here is not on discrimination based upon race, because even if employment discrimination laws would not apply, it is assumed that a race discrimination claim could be based on 42 U.S.C. $§$ 1981(b). See Lauture v. Int'l Bus. Mach. Corp., 216 F.3d 258 (2d Cir. 2000); Whidbee v. Garzarelli Food Specialties, Inc., 233 F.3d 62 (2d Cir. 2000); Tolton v. Day, No. 19945 (RDM), 2020 WL 2542129, at *20 (D.D.C. May 19, 2020); Bennett v. Pipe Work Sols., LLC, No. 1:17-CV-858-CLM, 2020 WL 1479154 (N.D. Ala. Mar. 26, 2020); Evans v. Columbia Univ., No. 14-CV-2658 (NSR), 2015 WL 1730097, at *5 (S.D.N.Y. Apr. 13, 2015). That said, the argument for application of oppression doctrine to contexts other than gender discrimination, such as discrimination based upon race, religion, age, or disability, could be applied with equal force.

12. See Peter Mahler, Minority Shareholder Oppression in the \#MeToo Era, N.Y. Bus. DIVORCE (Jan. 28, 2019), https://www.nybusinessdivorce.com/2019/01/articles/grounds-fordissolution/minority-shareholder-oppression-metoo-era/ [https://perma.cc/U3PJ-6RP4]. 
IN CLOSELY HELD FIRMS

firms to form Arcara, Zucarelli, Lenda \& Straka CPAs, P.C. ${ }^{13}$ Each founder made an equal capital contribution to the corporation, and each became an officer, director, and 25\% shareholder. ${ }^{14}$ Shortly thereafter, Straka alleged that a nonshareholder senior accountant, who was aware that she was an owner of the corporation, asked "Oh, are you the one who makes me coffee?" 15 He also asked whether he could "sit on" her lap and took her to look at a cartoon he posted on his office door that was "demeaning to women." " The unsolicited and humiliating behavior also extended to other women, and Straka and those women chose not to eat in the firm's lunchroom. ${ }^{17}$

Straka further alleges that the other shareholders did not involve her in decisions (including a decision to add a fifth shareholder, thereby diluting her ownership share to $20 \%$ ), and that they left her without sufficient staff. ${ }^{18}$ She alleges that the "earning matrix" used by the other shareholders resulted in her receiving the lowest compensation even though she had the second highest billing and revenue. ${ }^{19}$

For reasons explored in this Article, Straka would not likely have viable claims for employment discrimination because Straka is considered an owner, not an employee, for purposes of employment discrimination laws. This is the case even though the firm apparently recognized the risks of discrimination and harassment suits - it attempted to address the concerns of Straka and other women by contracting with a human resource company to provide sexual harassment seminars to the corporation's staff and shareholders. ${ }^{20}$

Where employment law falls short in combatting discrimination, the business law doctrine addressing minority owner oppression in the closely held entity may provide an avenue to seek relief. Minority oppression doctrine aims to protect minority investors in a closely held business from the abusive exercise of majority control. ${ }^{21}$ A "closely held" or "close" business is, by definition, one where there is a lack of ready market for ownership in the company. ${ }^{22}$ Often, a feature of the close business is that it has a small number of owners who have an active role in managing the company. ${ }^{23}$ Inherent in this structure is the opportunity for majority abuse because the minority owner lacks both exit and

13. Straka v. Arcara Zucarelli Lenda \& Assocs. CPAs, P.C., 92 N.Y.S.3d 567, 570 (Sup. Ct. 2019).

14. Id.

15. Id. at 571 .

16. Id. at $571-72$.

17. Id. at 571 .

18. Id. at 571-72.

19. Id. at 572 .

20. Id.

21. Douglas K. Moll, Shareholder Oppression and "Fair Value": Of Discounts, Dates, and Dastardly Deeds in the Close Corporation, 54 DukE L.J. 293, 293 (2004) [hereinafter Moll, DuKE].

22. Id. at 299-300.

23. Id. 
voice. ${ }^{24}$ That is, minority owners have no ready market to sell and exit the firm, and there are often transfer restrictions. ${ }^{25}$ Further, minority owners do not have enough of an ownership interest to change unfair practices. ${ }^{26}$ In the law of business organizations, oppression doctrine has developed to protect the minority owners, and it may be a useful tool to combat gender-based discrimination and harassment against a minority owner in a closely held business.

Whether framed as a breach of fiduciary duty or based upon a statutory ground for dissolution of the business entity, minority oppression occurs "when the majority conduct substantially defeats expectations that, objectively viewed, were both reasonable under the circumstances and were central to the [minority shareholder]'s decision to join the venture." ${ }^{27}$ Straka argued that, in co-founding the accounting firm, her expectations included that she would actively participate in management, that the compensation would be fairly distributed among shareholders, and that the corporation would be collaborative and more efficient in sharing information and staff. $^{28}$ Additionally, the court found that she reasonably expected that she would "be treated with equal dignity and respect as male shareholders forming the majority." 29

Section I of this Article will discuss the current jurisprudence addressing when an owner is an employee for purposes of employment discrimination statutes. Section II will explore the doctrine of minority shareholder oppression, both as an instrument of enforcing fiduciary obligations and as a statutory mechanism to petition for dissolution or seek other equitable relief. Section III will discuss how a female owner's claim of discrimination or harassment fits into existing minority oppression doctrine. Section III compares the substantive requirements of discrimination claims and oppression claims. This Article concludes that oppression doctrine presents a promising avenue of redress for owners to raise gender discrimination and harassment in closely held companies. One of the advantages of an oppression claim is that it need not be framed in gender-based terms to succeed. Indeed, in discrimination cases, it is often very difficult to prove that the employment decisions were based upon sex, and an oppression claim bypasses this requirement. However, this advantage in any individual case may also prove to be a greater overall disadvantage because, without framing the claim in gender-based terms, the broader goals of workplace equality are not advanced.

24. Benjamin Means, A Voice-Based Framework for Evaluating Claims of Minority Shareholder Oppression in the Close Corporation, 97 GEO. L.J. 1207, 1217 (2009) [hereinafter Means, GEO].

25. Id. at 1217.

26. Id.

27. In re Kemp \& Beatley, Inc., 473 N.E.2d 1173, 1179 (N.Y. 1984).

28. Straka v. Arcara Zucarelli Lenda \& Assocs. CPAs, P.C., 92 N.Y.S.3d 567, 570-71 (Sup. Ct. 2019).

29. Id. at 573. 


\section{THE EMPLOYMENT LAW GAP}

\section{A. Owners are Not Necessarily Employees for Purposes \\ of Discrimination Laws}

In any employment discrimination case, a threshold question is whether the plaintiff is an "employee." Where the plaintiff is an owner (a partner, shareholder, or member of an LLC), she may not benefit from the protections of employment discrimination laws because only "employees" are protected. The discrimination statutes are not helpful in defining who is an employee. For example, Title VII of the Civil Rights Act of 1964 (Title VII) provides the circular definition that an "employee" is "an individual employed by an employer."

In Clackamas Gastroenterology Associates, P.C., v. Wells, the U.S. Supreme Court identified six factors for determining whether a plaintiff owner is an "employee" for the purpose of the ADA:

1. Whether the organization can hire or fire the individual or set the rules and regulations of the individual's work;

2. Whether and, if so, to what extent the organization supervises the individual's work;

3. Whether the individual reports to someone higher in the organization;

4. Whether and, if so, to what extent the individual is able to influence the organization;

5. Whether the parties intended that the individual be an employee, as expressed in written agreements or contracts; and

6. Whether the individual shares in the profits, losses, and liabilities of the organization. ${ }^{31}$

Whether an individual is an "employee" under the six Clackamas factors depends on "'all of the incidents of the relationship." 32 The factors are not exclusive, no one factor is decisive, and they "cannot be decided in every case by a "shorthand formula or magic phrase." " 33 In sum, whether an owner is an employee within the meaning of the discrimination laws is a "fact-intensive inquiry." 34 The courts

30. 42 U.S.C.A. $\S 2000 \mathrm{e}(\mathrm{f})$ (West 2020). The corresponding provisions in the Americans with Disabilities Act (ADA), 42 U.S.C. $§$ 12111(4), and the Age Discrimination in Employment Act of 1967 (ADEA), 29 U.S.C. § 630(f), also contain "completely circular" definitions of "employee." See Clackamas Gastroenterology Assocs., P.C. v. Wells, 538 U.S. 440, 444 (2003) (discussing the "circular" definition of "employee" within these provisions).

31. Clackamas Gastroenterology Assocs., 538 U.S. at 449-50 (alteration in original) (quoting U.S. Equal Emp. Opportunity Comm’n, 2 Compliance Manual § 605:0009 (2000)).

32. Id. at 451 (quoting Nationwide Mut. Ins. Co. v. Darden, 503 U.S. 318, 324 (1992)).

33. Id. at 450 n.10 (quoting Darden, 503 U.S. at 324).

34. Magnotti v. Crossroads Healthcare Mgmt., LLC, 126 F. Supp. 3d 301, 311 (E.D.N.Y. 2015); see also Morales v. M. Alfonso Painting Corp., No. 11 Civ. 1263(NRB), 2013 WL 5289789, at *3 (S.D.N.Y. Sept. 19, 2013) (describing the inquiry under the Fair Labor Standards Act as, "[i]n this Circuit ... a fact-intensive inquiry that is 'grounded in economic reality rather than technical 
have applied this analysis beyond the ADA to the various statutes that prohibit discrimination in employment, including the Equal Pay Act (EPA) and Title VII, which, among other things, ban discrimination on the basis of sex. ${ }^{35}$ States have treated owners the same way under their own employment discrimination statutes. ${ }^{36}$

In Clackamas, the issue was whether four physicians who were shareholders and directors of defendant, a professional corporation, should be counted as "employees." ${ }^{37}$ The Supreme Court remanded for further fact finding in light of the factors it announced. The Court did, however, note that some of the district court's findings weighed in favor of the conclusion that the physician-owners were not employees - namely, that (i) the physician-owners controlled the operation of the clinic, (ii) they shared in the profits, and (iii) they were personally liable for malpractice claims. ${ }^{38}$ The question was important because if the four physicians were not "employees," defendant would not reach the threshold of fifteen employees, and the ADA would not apply to the defendant practice. ${ }^{39}$ Even though the six factors were announced in a case where the reason for asking whether the owners were employees was to determine the employee head count, the factors have since been applied by courts to determine whether plaintiff owners are employees who can themselves bring suit.

For example, in Campbell v. Chadbourne \& Parke LLP, plaintiffs were partners in a law firm and claimed, among other theories, pay discrimination and retaliation under federal and local discrimination statutes. ${ }^{40}$ The firm pointed to the partnership agreement, which gave the plaintiffs the title of "partner" and, on that basis, moved for summary judgment on the ground that plaintiffs were partners and not employees. ${ }^{41}$ The district court denied summary judgment,

concepts"” (quoting Irizarry v. Catsimatidis, 722 F.3d 99, 104 (2d Cir. 2013))).

35. Mariotti v. Mariotti Bldg. Prods., Inc., 714 F.3d 761, 766 (3d Cir. 2013) ("Because Title VII's definition of employee is the same as the ADA's definition, see 42 U.S.C. $\S \S$ $2000 \mathrm{e}(\mathrm{f}), 12111(4)$, and because the EEOC's guidelines, on which the Clackamas Court relied, apply to coverage under Title VII, the ADEA, the ADA, and the Equal Pay Act . . . we conclude that the analysis set out in Clackamas applies to Title VII as well.” (citing De Jesús v. LTT Card Servs., Inc., 474 F.3d 16, 24 (1st Cir. 2007))).

36. See, e.g., Hull v. Rose, Schmidt, Hasley \& DiSalle P.C., 700 A.2d 996, 1001 (Pa. Super. Ct. 1997) (construing Pennsylvania employment laws in light of comparable federal law to determine whether a partner is an employee); Weir v. Holland \& Knight, LLP, No. 603204/07, 2011 WL 6973240, at*5 (N.Y. Sup. Ct. Dec. 9, 2011) (applying Clackamas factors to determine whether a partner is considered an employee).

37. Clackamas Gastroenterology Assocs., 538 U.S. at 442.

38. Id. at 451 .

39. Title VII and the ADA exempt employers with fewer than fifteen employees. 42 U.S.C.A. $\S \S 2000 \mathrm{e}(\mathrm{b}), 12111(5)$ (West 2020). The threshold under the ADEA is twenty employees. 29 U.S.C.A. § 630(b) (West 2020).

40. Campbell v. Chadbourne \& Parke LLP, No. 16-CV-6832 (JPO), 2017 WL 2589389, at *1 (S.D.N.Y. June 14, 2017).

41. Id. at $* 3$. 
IN CLOSELY HELD FIRMS

holding that the terms of the operative partnership agreement did not automatically foreclose the possibility that plaintiffs may be considered employees. ${ }^{42}$ The court noted that:

The mere fact that a person has a particular title - such as partner, director, or vice president - should not necessarily be used to determine whether he or she is an employee or a proprietor, and the mere existence of a document styled, for example, as an "employment agreement," or a partnership agreement, does not necessarily answer the question. ${ }^{43}$

Therefore, the court allowed further discovery related to the Clackamas factors. ${ }^{44}$

The Campbell case is typical of the cases on this issue, which, given the multi-factor inquiry, is not a good candidate for summary judgment. ${ }^{45}$ No single factor is dispositive, but the touchtone of the cases is how much control the partner exercises over the firm, ${ }^{46}$ which is itself a matter of degree. While decisions have held as a matter of law both that a partner $\operatorname{can}^{47}$ and cannot ${ }^{48}$ sue as an employee, the cases deciding the issue as a matter of law are in the minority. The rulings have reached varying results, leaving the answer to this threshold question an "elusive" one still being "vetted" by the courts. ${ }^{49}$ Given this hurdle, the conventional wisdom is that, unless a partner truly has zero control of the firm, that partner's case for employment discrimination is simply too uncertain to pursue.

\section{B. The Closely Held Business as a Small Employer}

Even if the partner is deemed an "employee" with the right to sue for

42. $I d$. omitted).

43. Id. (quoting Clackamas Gastroenterology Assocs., 538 U.S. at 450) (internal quotations

44. Id. (citing Foresta v. Centerlight Capital Mgmt., LlC, 379 F. App'x 44, 46 (2d Cir. 2010)) (holding that "the District Court erred in granting summary judgment without first permitting plaintiff to take additional discovery" on a set of factors in the ADA context similar to the Clackamas factors, even though some discovery had been completed).

45. See Baskett v. Autonomous Research LLP, No. 17-CV-9237 (VSB), 2018 WL 4757962 (S.D.N.Y. Sept. 28, 2018); Campbell, 2017 WL 2589389; see also Kirleis v. Dickie, McCamey \& Chicolte, PC, No. 06-1495, 2007 WL 2142397 (W.D. Pa. July 24, 2007), aff'd, 560 F.3d 156 (3d Cir. 2009); Maxwell v. Jenkens \& Gilchrist, P.C., No. 3: 05-CV-0402-B ECF, 2006 WL 8437326 (N.D. Tex. Apr. 27, 2006).

46. Mariotti v. Mariotti Bldg. Prods., Inc., No. 3:11-CV-737, 2011 WL 2670570 at*3 (M.D. Pa. July 8, 2011), aff'd, 714 F.3d 761 (3d Cir. 2013).

47. See, e.g., E.E.O.C. v. Sidley Austin Brown \& Wood LLP, 406 F. Supp. 2d 991 (N.D. Ill. 2005), aff'd sub nom. E.E.O.C. v. Sidley Austin LLP, 437 F.3d 695 (7th Cir. 2006).

48. See, e.g., Solon v. Kaplan, 398 F.3d 629 (7th Cir. 2005); Ziegler v. Anesthesia Assocs. of Lancaster, Ltd., 74 F. App'x 197 (3d Cir. 2003); Pearl v. Monarch Life Ins. Co., 289 F. Supp. 2d 324 (E.D.N.Y. 2003).

49. Mulvaney, supra note 10. 
employment discrimination, employers with fewer than fifteen employees are exempt from Title VII. ${ }^{50}$ The number of employees is also relevant to statutory caps on damages. For example, under Title VII, a firm with between fifteen and one hundred employees can be liable for only $\$ 50,000$ in punitive and compensatory damages, while liability for a firm with more than 500 employees is capped at $\$ 300,000 . .^{51}$ It is worth noting that the number of employees is irrelevant to the minority oppression analysis.

In sum, even if the plaintiff owner were to be deemed an employee able to assert discrimination claims, another reason why minority oppression may be needed as an alternative avenue to relief is that the firm may not be large enough to come within Title VII,${ }^{52}$ or the size of the firm may limit the right to damages.

\section{SHAREHOLDER OPPRESSION IN THE CLOSELY HELD BUSINESS}

This Section will provide an overview of the oppression doctrine in the closely held corporation, exploring statutory and common law avenues for relief. It will also discuss the application of the doctrine to other business organizations, such as the limited liability partnership or limited liability company. It includes a discussion of the wide range of available remedies for minority oppression.

\section{A. Oppression in the Closely Held Corporation}

A closely held corporation typically has a small number of stockholders, an absence of a ready market for ownership in the corporation, and active and meaningful shareholder participation in corporate management. ${ }^{53}$ The closely held corporation is often contrasted with the traditional, public corporation, where management is centralized in the hands of a board of directors, and shareholders are ordinarily passive investors, not actively engaged in the management of the

50. Indeed, in Clackamas, the plaintiff alleging discrimination was an employee bookkeeper, not a physician-owner of the medical practice. The Supreme Court addressed whether the physician-owners were employees of the practice for the purpose of determining whether the practice met the 15-employee threshold to come within the ADA. See Clackamas Gastroenterology Assocs., P.C. v. Wells, 538 U.S. 440, 442 (2003). Notably, the EPA does not have a similar exemption and could apply to employers with fewer than fifteen employees. See 4 Ivan E. Bodensteiner \& Rosalie Berger Levinson, State and Local Government Civil Rights LIABILITY § 7:23 (2020).

51. 42 U.S.C.A. $§ 1981 \mathrm{a}(\mathrm{b})(3)(\mathrm{A})$, (D) (West 2020).

52. Many state statutes set the exemption at a lower number of employees. See Discrimination - Employment Laws, NAT'L CONF. ST. LEGISLATURES, https://www.ncsl.org/ documents/employ/Discrimination-Chart-2015.pdf (last visited Nov. 17, 2020) [https://perma.cc/ 3F5A-88XN] (chart collecting threshold number of employees for state statutes to apply).

53. Moll, DuKe, supra note 21, at 299 (citing Daniel S. Kleinberger, Why Not Good Faith? The Foibles of Fairness in the Law of Close Corporations, 16 WM. MitcheLl L. ReV. 1143, 1148 (1990) [hereinafter Kleinberger, WM. Mitchell]). Moll notes that definitions of the close corporation vary, but the various definitions capture the common attributes of the closely held corporation. Id. at 299 n. 15 . 
IN CLOSELY HELD FIRMS

corporation. $^{54}$ "Close corporation shareholders 'usually expect employment and a meaningful role in management, as well as a return on the money paid for [their] shares." ",55

In a corporation, the board is ordinarily chosen by a majority vote of the shareholders. ${ }^{56}$ Thus, in a closely held corporation, "the board is ordinarily controlled 'by the shareholder or shareholders holding a majority of the voting power." 57 This majority rule, which is typical of the public corporation, raises concerns about abuse of power in the closely held corporation, where the shareholders, including minority shareholders, may very well expect active participation and employment in the firm. In the publicly held corporation, if a shareholder is not happy with the majority rule, they have the ready market remedy of selling their shares. ${ }^{58}$ By definition, and by default, there is no ready exit for a shareholder in a closely held corporation. ${ }^{59}$ Indeed, the majority shareholders in the closely held corporation may use this majority position "to take actions that are harmful to the minority shareholder's interests." 60 "Such actions are often referred to as 'freeze-out' or 'squeeze-out' techniques that 'oppress' the close corporation minority shareholder." ${ }^{\prime 61}$ Professor Douglas Moll explains:

Common freeze-out techniques include the refusal to declare dividends, the termination of a minority shareholder's employment, the removal of a minority shareholder from a position of management, and the siphoning off of corporate earnings through high compensation to the majority shareholder. Quite often, these tactics are used in combination. For example, a close corporation investor generally looks to salary more than dividends for a share of the business returns because the "[e]arnings of a close corporation often are distributed in major part in salaries, bonuses and retirement benefits." When actual dividends are not paid, a minority shareholder who is discharged from employment and removed from the board of directors is effectively denied any return on his investment as well as any input into the management of the business. Once a minority shareholder faces this "indefinite future with no return on the capital he or she contributed to the enterprise," the majority often proposes to purchase the shares of the minority shareholder at an unfairly low price. ${ }^{62}$

54. Id. at 300 .

55. Id. (alteration in original) (quoting Robert B. Thompson, The Shareholder's Cause of Action for Oppression, 48 Bus. LAw. 699, 702 (1993) [hereinafter Thompson, Bus.]).

56. Id. at 299-300.

57. Id. at 301 (quoting Kleinberger, WM. MitcheLL, supra note 53, at 1151-52).

58. Id. at 303.

59. Id.

60. Id. at 301 .

61. Id.

62. Id. 
Thus, a concern of corporate law doctrine is that a minority shareholder in a closely held corporation is vulnerable to unfair treatment by the majority shareholders, and there is no ready exit from the firm by selling the shares at a fair price. ${ }^{63}$

The textbook example of minority oppression occurred in Wilkes $v$. Springside Nursing Home, Inc. ${ }^{64}$ In that case, the plaintiff (Wilkes) acquired an option to purchase a building and lot in Pittsfield, Massachusetts. ${ }^{65}$ Wilkes and three acquaintances decided to participate jointly in the purchase of the building and lot as a real estate investment which, they believed, had good potential for profit if operated as a nursing home called Springside. ${ }^{66}$ Each of the four men invested $\$ 1,000$ and held ten shares of stock. ${ }^{67}$ At the time of incorporation, each party understood that they would be a director of Springside and would actively participate in the management and decision making involved in operating the corporation. ${ }^{68}$ Each party also understood and intended to receive money from the corporation in equal amounts as long as each assumed an active and ongoing responsibility for carrying a portion of the burdens necessary to operate the business. ${ }^{69}$

A year in, the profit from the business was large enough for each shareholder to draw a salary. ${ }^{70}$ Eventually, the personal relationship between Wilkes and the three other men soured. ${ }^{71}$ At a meeting of the directors, Wilkes' salary was terminated. ${ }^{72}$ At a shareholder meeting, they did not reelect Wilkes as a director, and he was ultimately informed that neither his services nor his presence at the nursing home were wanted by his associates. ${ }^{73}$ The severance of Wilkes from the payroll resulted not from misconduct or neglect of duties, but because of the personal desire of the other three investors to prevent him from continuing to receive money from the corporation. ${ }^{74}$ Wilkes gave notice of his intention to sell his shares for an amount based on an appraisal of their value, but the best he was offered was a price for which one of the investors admitted he would not have taken for his own shares. ${ }^{75}$

This was a classic example of a "freeze out" because Wilkes had a reasonable expectation that, in investing in the corporation, he would continue to participate

63. Id.

64. Wilkes v. Springside Nursing Home, Inc., 353 N.E.2d 657, 662 (Mass. 1976).

65. Id. at 659 .

66. Id.

67. Id.

68. Id. at 660 .

69. Id.

70. Id.

71. Id. at 661 .

72. Id.

73. Id.

74. Id.

75. Id. 
IN CLOSELY HELD FIRMS

in management and receive a salary. ${ }^{76}$ Indeed, the salary was his return on investment. ${ }^{77}$ Once he was severed from the payroll and no longer on the board, he wanted to exit the corporation, but there was no ready market for his shares, and his fellow investors only offered him an unfair price. ${ }^{78}$ Given the lack of ready exit, minority oppression doctrine, whether based in statutory law or common law fiduciary principles, aims to protect the minority shareholders like Wilkes from abuse of the majority's power.

\section{B. Minority Oppression Claims in the Closely Held Corporation}

There are both common law and legislative avenues for a minority shareholder in a closely held corporation to challenge oppression by the majority shareholders. First, and a relatively recent development, many states have added to their corporate statutes the right of a minority shareholder in a closely held corporation to petition for judicial dissolution of the corporation based on oppression..$^{79}$ Second, many courts, especially where there is no statutory right to petition for dissolution, have recognized a fiduciary duty of the majority shareholders in a closely held corporation to the minority shareholders, and have permitted breach of fiduciary duty claims to proceed on the basis of minority oppression. ${ }^{80}$

1. Statutory Cause of Action for Minority Oppression.-In the mid-1970s and early 1980 s, several states enacted statutes to protect minority shareholders in closely held corporations. ${ }^{81}$ A number of state statutes and the Model Business Corporation Act (MBCA) allow a minority shareholder in a closely held corporation to petition for dissolution based upon minority oppression. ${ }^{82}$ While some of the statutes expressly include a standard that looks to the "reasonable expectations" of the minority shareholder, ${ }^{83}$ other statutes have left the definition of "minority oppression" to the courts. ${ }^{84}$

For example, neither the MBCA nor the New York Business Corporation Law defines "oppressive acts." ${ }^{\prime 5}$ The New York Court of Appeals has defined

76. Id.

77. Id.

78. Id.

79. See 2 F. Hodge O’Neal \& Robert B. Thompson, Close Corporations \& LlCs: Law AND PRACTICE $\S 9: 18$ (Rev. 3d ed. 2020) [hereinafter O’NeAl \& THOMPSON] (chart of state statutes).

80. Id.; Moll, DuKE, supra note 21, at 304.

81. John H. Matheson \& R. Kevin Maler, A Simple Statutory Solution to Minority Oppression in the Closely-Held Business, 91 MinN. L. REV. 657, 665 (2007).

82. Id. at app. The Appendix collects various state statutes. See Model Bus. Corp. Act $\S$ 14.30(2)(ii) (AM. BAR AsS'N 2006).

83. See N.D. Cent. Code $§ 10-19.1-115$ (2001).

84. Matheson \& Maler, supra note 81, at 666.

85. Model Bus. Corp. Act $\S 14.30(2)($ ii) (Am. Bar Ass'n 2006); N.Y. Bus. Corp. Law $\S$ 1104-a(a) (McKinney 2020). 
"oppression" as "when the majority conduct substantially defeats the expectations that, objectively viewed, were both reasonable under the circumstances and were central to the [minority shareholder]'s decision to join the venture." ${ }^{86}$ The Virginia Supreme Court, interpreting its own judicial dissolution statute, which is based on the MBCA, defined the term "oppressive" as "conduct by corporate managers toward stockholders which departs from the standards of fair dealing and violates the principles of fair play on which persons who entrust their funds to a corporation are entitled to rely." 87

Some statutes, either in addition to "oppression" or instead of the term "oppression," provide "persistent unfairness," "unfairly prejudicial," or "willfully unfair" conduct as a ground for a minority shareholder to petition for dissolution. ${ }^{88}$ Even if broader in scope, the term "unfairly prejudicial" is similar to the term "oppressive." 89 The North Carolina statute simply references the "rights and interests" of the minority shareholder and does not reference oppression or other majority conduct. ${ }^{90}$ Nevertheless, in Meiselman v. Meiselman, the North Carolina Supreme Court determined that the "rights or interests" of a complaining shareholder, as set forth in the North Carolina statute, include the "reasonable expectations" the shareholder has in the corporation. ${ }^{91}$ All to say, whatever the exact language used, the statutes seem to be concerned with protecting the reasonable expectations of the minority shareholder in investing in the firm and preventing unfair conduct by the majority.

Indeed, in Meiselman v. Meiselman, the North Carolina Supreme Court provided guidance on how to determine the "reasonable expectations" of a minority shareholder:

These "reasonable expectations" are to be ascertained by examining the entire history of the participants' relationship. That history will include the "reasonable expectations" created at the inception of the participants" relationship; those "reasonable expectations" as altered over time; and the "reasonable expectations" which develop as the participants engage in a course of dealing in conducting the affairs of the corporation. The

86. In re Kemp \& Beatley, Inc., 473 N.E.2d 1173, 1179 (N.Y. 1984); see also Brenner v. Berkowitz, 634 A.2d 1019 (N.J. 1993) (recognizing that "[o]ppression has been defined as frustrating a shareholder's reasonable expectations"); Robert C. Art, Shareholder Rights and Remedies in Close Corporations: Oppression, Fiduciary Duties, and Reasonable Expectations, 28 J. CORP. L. 371, 390 n.126 (2003) (collecting cases applying reasonable expectations standard).

87. Giannotti v. Hamway, 387 S.E.2d 725, 730 (Va. 1990).

88. Douglas K. Moll, Shareholder Oppression v. Employment at Will in the Close Corporation: The Investment Model Solution, 1999 U. ILL. L. REV. 517, 526 n.41 [hereinafter Moll, ILL.] (citing 1 F. Hodge O'Neal \& Robert B. Thompson, O’NEAL'S Close CoRporations $§ 9.29$, at 134, 139 n.27 (3d ed. 1996) (collecting statutes)). See, e.g., Cal. Corp. Code $§ 1800$ (West 1990) (“persistent unfairness"); MicH. COMP. LAWs $§ 450.1489$ (1988) (“willfully unfair”); MiNN. StAT. ANN. § 302A.751 (West Supp. 1999) (“unfairly prejudicial”).

89. Thompson, Bus., supra note 55, at 702, 709 n.70.

90. N.C. Gen. Stat. AnN. § 55-14-30(2)(ii) (West 2020).

91. Meiselman v. Meiselman, 307 S.E.2d 551, 563-64 (N.C. 1983). 
interests and views of the other participants must be considered in determining "reasonable expectations." The key is "reasonable." In order for plaintiff's expectations to be reasonable, they must be known to or assumed by the other shareholders and concurred in by them. Privately held expectations which are not made known to the other participants are not "reasonable." Only expectations embodied in understandings, express or implied, among the participants should be recognized by the court. ${ }^{92}$

Another variation among the statutes is who may petition for dissolution. Most statutes limit the remedy of judicial dissolution to the closely held corporation but define a closely held corporation differently. For example, in New York, the judicial dissolution statute only applies to corporations not "registered as an investment company under an act of congress entitled "Investment Company Act of 1940." "'93 Other states define the "closely held corporation" as a corporation that has few shareholders and whose corporate shares are not traded on a securities market. ${ }^{94}$ Under Minnesota common law, a closely held corporation "is identified by three characteristics: (1) shareholders are usually active in the business; (2) there is usually no market for a minority interest in the stock; and (3) dividends are seldom distributed." ${ }^{\prime 5}$ In Texas, by statute, to be a closely held corporation, the company must have "fewer than 35 shareholders" and "no shares listed on a national securities exchange or regularly quoted in an over-the-counter market by one or more members of a national securities association." 96

In addition, the statutes vary in whether they set a minimum percentage of interest that a minority shareholder (or group of shareholders) must hold in order to have the right to petition for dissolution. The MBCA does not set a minimum percentage of ownership for a shareholder to have standing to petition for dissolution on the ground of oppression $;{ }^{97}$ neither does Maryland. ${ }^{98}$ In New York and Georgia, for example, only "shares representing twenty percent or more of the votes of all outstanding shares of a corporation" may petition for dissolution. ${ }^{99}$

While dissolution is an available statutory remedy for oppression, an order

92. Id. at 563 .

93. N.Y. Bus. CorP. LAw $\S 1104-a(a)$ (McKinney 2020).

94. See Brothers v. Winstead, 129 So. 3d 906, 918 (Miss. 2014); Crosby v. Beam, 548 N.E.2d 217, 220 (Ohio 1989); Sneed v. Webre, 465 S.W.3d 169, 177 (Tex. 2015); N. Air Servs., Inc. v. Link, 804 N.W.2d 458, 463 n.5 (Wisc. 2011).

95. U.S. Bank N.A. v. Cold Spring Granite Co., 802 N.W.2d 363, 381 (Minn. 2011) (citing Westland Capital Corp. v. Lucht Eng'g Inc., 308 N.W.2d 709, 712 (Minn. 1981)).

96. Tex. Bus. Orgs. Code Ann. § 21.563 (West 2019).

97. Model Bus. Corp. ACt $\S 14.30(2)($ ii) (Am. BAR Ass'n 2006).

98. MD. CODE ANN., CORPS. \& Ass'NS § 3-413(b)(2) (West 2020) (“any stockholder entitled to vote" may petition for dissolution based on oppression).

99. N.Y. Bus. Corp. LAW § 1104-a(a) (McKinney 2020); see also GA. CodE ANN. § 14-21430(2)(B) (West 2020) (holders of at least 20\% of all outstanding shares may petition for dissolution based on oppression). 
of dissolution is not always granted. ${ }^{100}$ This is, in part, because many statutes allow the majority shareholders to buy out the petitioning shareholder for "fair value" to prevent dissolution. ${ }^{101}$ Further, the statutes and courts have authorized "alternative remedies that are less drastic than dissolution." 102 For example, the Minnesota and New Jersey statutes authorize a range of equitable relief. ${ }^{103}$ In Baker v. Commercial Body Builders, Inc., the Supreme Court of Oregon catalogued the range of equitable remedies available for oppressive conduct as an alternative to dissolution. ${ }^{104}$ The Oregon Court listed the following possibilities:

(a) The entry of an order requiring dissolution of the corporation at a specified future date, to become effective only in the event that the stockholders fail to resolve their differences prior to that date;

(b) The appointment of a receiver, not for the purposes of dissolution, but to continue the operation of the corporation for the benefit of all the stockholders, both majority and minority, until differences are resolved or 'oppressive' conduct ceases;

(c) The appointment of a 'special fiscal agent' to report to the court relating to the continued operation of the corporation, as a protection to its minority stockholders, and the retention of jurisdiction of the case by the court for that purpose;

(d) The retention of jurisdiction of the case by the court for the protection of the minority stockholders without appointment of a receiver or 'special fiscal agent';

(e) The ordering of an accounting by the majority in control of the corporation for funds alleged to have been misappropriated;

(f) The issuance of an injunction to prohibit continuing acts of 'oppressive' conduct and which may include the reduction of salaries or bonus payments found to be unjustified or excessive;

(g) The ordering of affirmative relief by the required declaration of a dividend or a reduction and distribution of capital;

(h) The ordering of affirmative relief by the entry of an order requiring the corporation or a majority of its stockholders to purchase the stock of the minority stockholders at a price to be determined according to a specified formula or at a price determined by the court to be a fair and reasonable price;

(i) The ordering of affirmative relief by the entry of an order permitting

100. Moll, ILL., supra note 88, at 526-27.

101. See Model Bus. Corp. Act § 14.31(d) (Am. BAr Ass'n 2006); N.Y. Bus. Corp. Law $\S 1118$ (McKinney 2020).

102. Moll, ILL., supra note 88 , at 526.

103. N.J. Stat. AnN. § 14A:12-7(1)(c) (West 2003); Minn. Stat. AnN. § 302A.751 subd. 1 (West 1999); see also Moll, ILL., supra note 88, at 527 n.2; Matheson \& Maler, supra note 81, at 670 .

104. Baker v. Commercial Body Builders, Inc., 507 P.2d 387, 395-96 (Or. 1973) (citations and footnotes omitted). 
minority stockholders to purchase additional stock under conditions specified by the court;

(j) An award of damages to minority stockholders as compensation for any injury suffered by them as the result of 'oppressive' conduct by the majority in control of the corporation. ${ }^{105}$

Given this range of potential remedies, minority oppression has "evolved from a ground for involuntary dissolution to a ground for a wide variety of relief," referred to as " "the statutory cause of action for oppression.""106

2. Oppression as Breach of Fiduciary Duty.- "Many courts now recognize an enhanced fiduciary duty in a close corporation setting, based on the particular characteristics of the close corporation relationship." 107 Particularly where there is no statutory cause of action for oppression, courts have held that minority oppression is a breach of the fiduciary duty that the majority stockholders owe to the minority. ${ }^{108}$ "The dissolution statutes do not provide the exclusive remedies for oppressed shareholders; courts have equitable powers to fashion appropriate remedies where the majority shareholders have breached their fiduciary duty to the minority by engaging in oppressive conduct."109

The courts have looked to the partnership law as a model, holding that shareholders in a closely held corporation "owe one another substantially the same fiduciary duty in the operation of the enterprise that partners owe to one another." 110 Oppression is a breach of the duty of loyalty because, in essence, the majority shareholders have appropriated the gains of the corporation for themselves at the expense of the minority shareholder. ${ }^{111}$ The courts have permitted minority shareholders in closely held corporations to pursue oppression claims as direct claims (rather than as derivative suits). ${ }^{112}$

The fiduciary duty analysis reflects the "the same underlying concerns" as the statutory cause of action for oppression, and can essentially be understood as "two manifestations" of the same cause of action, ${ }^{113}$ or "two sides of the same coin." 114 In analyzing whether there was a breach of fiduciary duty, the courts still

105. Id. (citations and footnotes omitted).

106. Moll, ILL., supra note 88, at 527.

107. O’Neal \& Thompson, supra note 79.

108. Douglas K. Moll, Reasonable Expectations v. Implied-in-Fact Contracts: Is the Shareholder Oppression Doctrine Needed?, 42 B.C. L. REv. 989, 1001 (2001) [hereinafter Moll, B.C.].

109. Hollis v. Hill, 232 F.3d 460, 468 (5th Cir. 2000).

110. See, e.g., Donahue v. Rodd Electrotype Co., 328 N.E.2d 505, 515 (Mass. 1975); see also Means, GEO, supra note 24, at 1223-26.

111. Hollis, 232 F.3d at 466 (framing oppression claim as breach of duty of loyalty); accord Rexford Rand Corp. v. Ancel, 58 F.3d 1215, 1219 (7th Cir. 1995).

112. O’NeAl \& ThOMPSON, supra note 79.

113. Thompson, Bus., supra note 55, at 700, 738-39.

114. Moll, B.C., supra note 108, at 1001. 
weigh whether the majority shareholders frustrated the "reasonable expectations" of the minority. ${ }^{115}$ For example, in the Wilkes case, the Supreme Judicial Court of Massachusetts held that Wilkes had been frozen out by the other shareholders because he, "like the others, had invested his capital and time for more than fifteen years with the expectation that he would continue to participate in corporate decisions." emphasized that the expectation that the minority shareholder claims was frustrated must be a reasonable expectation. ${ }^{117}$

In the absence of a statutory claim and in fashioning an appropriate analysis, the Wilkes court recognized that the "majority, concededly, have certain rights to what has been termed 'selfish ownership' in the corporation which should be balanced against the concept of their fiduciary obligation to the minority."118 Thus, it initially placed the burden on the majority to demonstrate a legitimate business purpose for their actions toward Wilkes. ${ }^{119}$ If the majority meets this burden, the burden shifts to the minority shareholder "to demonstrate that the same legitimate objective could have been achieved through an alternative course of action less harmful to the minority's interest." 120 The court should then "weigh the legitimate business purpose, if any, against the practicability of a less harmful alternative." 121

In Wilkes, the three majority stockholders were not able to show "a legitimate business purpose for severing Wilkes from the payroll of the corporation or for refusing to reelect him as a salaried officer and director." 122 The case was remanded for a determination of damages, allowing Wilkes to recover ratably from each of the majority shareholders "the salary he would have received had he remained an officer and director" of the corporation. ${ }^{123}$

In cases where the majority shareholders have breached a fiduciary duty to the minority, the remedy is "to restore [the minority shareholder] as nearly as possible to the position [s] he would have been in had there been no" oppression. ${ }^{124}$ Because oppression constitutes the frustration of the reasonable expectations of the minority shareholder, the remedy aims to restore the minority's reasonable expectations, to the extent possible, with those benefits the

115. Id. at 1001-02.

116. Wilkes v. Springside Nursing Home, Inc., 353 N.E.2d 657, 664 (Mass. 1976).

117. See, e.g., Merola v. Exergen Corp., 668 N.E.2d 351, 354 (Mass. 1996); McLaughlin v. Schenk, 220 P.3d 146, 157 (Utah 2009), abrogated on other grounds by Haik v. Jones, 427 P.3d 1155 (Utah 2018); Hollis v. Hill, 232 F.3d 460, 471 (5th Cir. 2000).

118. Wilkes, 353 N.E.2d at 663.

119. Id.

120. $I d$.

121. Id.

122. Id. at 663-64.

123. Id. at 664 .

124. Brodie v. Jordan, 857 N.E.2d 1076, 1080 (Mass. 2006) (quoting Zimmerman v. Bogoff, 524 N.E.2d 849, 855 (Mass. 1988)). 
minority reasonably expected. ${ }^{125}$ In Brodie v. Jordan, the Supreme Judicial Court of Massachusetts opined:

If, for example, a minority shareholder had a reasonable expectation of employment by the corporation and was terminated wrongfully, the remedy may be reinstatement, back pay, or both. Similarly, if a minority shareholder has a reasonable expectation of sharing in company profits and has been denied this opportunity, she may be "entitled to participate in the favorable results of operations to the extent that those results have been wrongly appropriated by the majority." The remedy should neither grant the minority a windfall nor excessively penalize the majority. Rather, it should attempt to reset the proper balance between the majority's "concede[d] . . . rights to what has been termed 'selfish ownership," and the minority's reasonable expectations of benefit from its shares. ${ }^{126}$

Therefore, where an oppression claim is framed as a breach of fiduciary duty, the remedy should aspire to restore the reasonable expectation of the minority shareholder that was frustrated by the majority's actions.

\section{Oppression in the LLC or Partnership}

Minority oppression doctrine has developed in the context of closely held corporations, but it has been applied to other business organizations, such as the limited liability partnership or limited liability company (LLC). For example, in Alloy v. Wills Family Trust, a Maryland appellate court recognized that partners in a partnership that is not structured to provide for ready exit are "vulnerable to the same type of squeezing and freezing commonly seen in other forms of privately held business entities, including close corporations and limited liability companies." ${ }^{127}$ In the absence of a statutory mechanism to address oppression, the courts have turned to fiduciary principles. ${ }^{128}$

In the past twenty-five or so years, the LLC has "exploded" in popularity as the entity form of choice for a small business. ${ }^{129}$ The Uniform Limited Liability Company Act of 2006 ("ULLCA") was revised to expressly provide that an LLC

125. Id.

126. Id. (internal citations omitted).

127. Alloy v. Wills Family Tr., 944 A.2d 1234, 1263 (Md. Ct. Spec. App. 2008) (citing Franklin A. Gevurtz, Preventing Partnership Freeze-Outs, 40 MERCER L. REV. 535, 573-74 (1989), and Sandra K. Miller, What Buy-Out Rights, Fiduciary Duties, and Dissolution Remedies Should Apply in the Case of the Minority Owner of a Limited Liability Company?, 38 HARV. J. ON LEGIS. 413, 436 (2001)); see also Sugarman v. Sugarman, 797 F.2d 3 (1st Cir. 1986) (applying freeze out analysis in partnership).

128. Alloy, 944 A.2d at 1264-65 (collecting cases).

129. Douglas K. Moll, Minority Oppression \& the Limited Liability Company: Learning (or Not) from Close Corporation History, 40 WAKE FOREST L. REV. 883, 885-86 (2005) [hereinafter Moll, WAKE FOREST]. 
member may bring an application for dissolution on the ground that the LLC managers or those in control of the company "have acted or are acting in a manner that is oppressive and was, is, or will be directly harmful to the applicant." ${ }^{130}$ Indeed, the comment to this ULLCA provision acknowledges that "[c]ourts have extrapolated close corporation doctrine to unincorporated organizations." 131 The ULLCA is presently enacted as law in over twenty states. ${ }^{132}$

There are a number of states that do not provide an express statutory mechanism to address minority oppression. For example, both the Delaware and New York statutes solely provide that a member may petition for dissolution of the LLC "whenever it is not reasonably practicable to carry on the business in conformity with a limited liability company agreement." ${ }^{133}$ Nevertheless, in those jurisdictions, the courts may justify the application of the oppression doctrine based on fiduciary principles. ${ }^{134}$

\section{APPLICATION OF MINORITY OPPRESSION DOCTRINE TO GENDER-BASED DISCRIMINATION}

Where employment law fails to provide relief, or renders the availability of relief uncertain, oppression doctrine may provide on owner with an avenue to redress harassment and/or discrimination. The remarkable promise of applying oppression doctrine to combat harassment and discrimination is that it need not necessarily be framed in gender-based terms. At the same time, a disadvantage of not framing the claim in gender-based terms is that broader goals of workplace equality are not advanced.

Revisiting Diana Straka's case is instructive. Recall that she was a 25\% owner in an accounting firm organized as a closely held corporation. ${ }^{135}$ Straka alleged harassment as well as unfair treatment - namely, that the other owners failed to involve her in decision making and that she did not receive

130. Unif. Ltd. Liab. Co. Act § 701(a)(4)(C)(ii) (2006) (Unif. Law Comm’n, amended 2013).

131. Id. cmt. (citing Alloy, 944 A.2d at 1262-64 (discussing cases)); see also Gardner v. Larkin, No. 19-139JJM, 2020 WL 831860, at *26 (D.R.I. Feb. 20, 2020) (applying oppression doctrine to members in LLC), report and recommendation adopted, No. 19-139-JJM-PAS, 2020 WL 1502300 (D.R.I. Mar. 30, 2020) (The ULLCA comment notes that, in applying oppression doctrine to an LLC, "many cases simply conflate the two contexts" of the close corporation and the LLC).

132. Limited Liability Company Act, Revised, UNIF. LAw COMM'N, https://www.uniformlaws. org/committees/community-home?communitykey=bbea059c-6853-4f45-b69b-7ca2e49cf 740\&tab=groupdetails (last visited Sept. 30, 2020) [https://perma.cc/U4LZ-SXHK].

133. See Del. Code Ann. tit. 6, § 18-802 (2020); N.Y. Ltd. Liab. Co. LaW $§ 702$ (McKinney 2019).

134. Moll, WAKE FOREST, supra note 129, at 957, 965-67.

135. Straka v. Arcara Zucarelli Lenda \& Assocs. CPAs, P.C., 92 N.Y.S.3d 567, 569-70 (Sup. Ct. 2019). 
IN CLOSELY HELD FIRMS

compensation that fairly reflected her contributions to the firm's revenue. ${ }^{136}$ Straka's reasonable expectations in co-founding the firm and holding a $25 \%$ interest were that she would actively participate in management and that the compensation would be fairly distributed among the owners. ${ }^{137}$ To establish oppression, Straka needed only to demonstrate that her reasonable expectations had been frustrated - that she was not treated with equal dignity and respect as the other shareholders. Were Straka, instead, a man, with three other male cofounders, her case would look a lot like Wilkes. ${ }^{138}$

Wilkes did not frame his oppression claim in gendered terms - the facts would not have supported that assertion, and it was also completely unnecessary. ${ }^{139}$ Wilkes, who co-founded a corporation to operate a nursing home with three other shareholders, had a reasonable expectation of continued participation in management and compensation for his efforts on behalf of the company. ${ }^{140}$ The Wilkes court held that his reasonable expectations of investing had been frustrated. ${ }^{141}$

In Straka, the court additionally found that Straka reasonably expected that she would "be treated with equal dignity and respect as male shareholders forming the majority." " 42 It is encouraging that the court recognized the genderbased element of the harassment and unfair treatment because it serves to vindicate Straka's sense that the root of the unfair treatment and harassment was gender bias, and it allows her story to be fully heard. It also furthers antidiscrimination policy, even though employment discrimination statutes are not applied. That said, Straka's claims would have been viable even without genderbased reasonable expectations. Simply stating that she reasonably expected to be treated fairly as an equal owner and not to be harassed, as any of the owners might have claimed regardless of gender, would have been sufficient to assert grounds for oppression.

\section{A. The Hope of Oppression Doctrine}

1. Disparate Treatment v. Minority Oppression.--Recognizing that a Title VII plaintiff is unlikely to have "direct" evidence of an employer's intent to discriminate, McDonnell Douglas Corp. v. Green established a well-known burden shifting framework for circumstantial proof of employment discrimination. ${ }^{143}$ Curiously, the burden shifting announced in Wilkes is

136. Id. at $569-72$.

137. Id. at 570-71.

138. Wilkes v. Springside Nursing Home, Inc., 353 N.E.2d 657, 657 (Mass. 1976).

139. See id.

140. See id.

141. Id. at 664-65.

142. Straka, 92 N.Y.S.3d at 573.

143. McDonnell Douglas Corp. v. Green, 411 U.S. 792, 801-05 (1973). While Title VII requires a showing of discriminatory intent, under the EPA, liability is assumed if there is a wage differential for a substantially equivalent role and no affirmative defense is established. See Brian 
structurally similar to the burden shifting paradigm established for disparate impact claims in McDonnell Douglas. ${ }^{144}$ Side by side, they look like this:

\begin{tabular}{|c|c|c|}
\hline & $\begin{array}{c}\text { Disparate Treatment - McDonnell } \\
\text { Douglas (Employment Doctrine) }\end{array}$ & $\begin{array}{c}\text { Minority Oppression - Wilkes } \\
\text { (Corporate Doctrine) }\end{array}$ \\
\hline $\begin{array}{c}\text { Initial } \\
\text { Burden }\end{array}$ & $\begin{array}{l}\text { On plaintiff/employee to make out } \\
\text { prima facie case: } \\
\text { 1. The employee is a member of a } \\
\text { protected class; } \\
\text { 2. The discriminator knew of the } \\
\text { employee's protected class; } \\
\text { 3. Acts of harm occurred; and } \\
\text { 4. Others who were similarly situated } \\
\text { were either treated more favorably or } \\
\text { not subjected to the same or similar } \\
\text { adverse treatment. }\end{array}$ & $\begin{array}{l}\text { On plaintiff/minority owner to } \\
\text { establish reasonable expectations } \\
\text { in investing in the firm have } \\
\text { been frustrated (i.e., that there is } \\
\text { oppression). }{ }^{146}\end{array}$ \\
\hline $\begin{array}{l}\text { Burden } \\
\text { Shifts }\end{array}$ & $\begin{array}{l}\text { To defendant/employer to provide a } \\
\text { legitimate, non-discriminatory reason } \\
\text { for its actions. }{ }^{147}\end{array}$ & $\begin{array}{l}\text { To defendants/majority owners } \\
\text { to show a "legitimate business } \\
\text { purpose" for actions taken } \\
\text { against minority. }{ }^{148}\end{array}$ \\
\hline $\begin{array}{c}\text { Burden } \\
\text { Shifts Back }\end{array}$ & $\begin{array}{l}\text { To plaintiff/employee to demonstrate } \\
\text { that the employer's reason is merely a } \\
\text { pretext for discrimination. }{ }^{149}\end{array}$ & $\begin{array}{l}\text { To plaintiff/minority owner "to } \\
\text { demonstrate that the same } \\
\text { legitimate objective could have } \\
\text { been achieved through an } \\
\text { alternative course of action less } \\
\text { harmful to the minority's } \\
\text { interest."."150 }\end{array}$ \\
\hline
\end{tabular}

Under McDonnell Douglas, the initial burden on the plaintiff/employee to establish a prima facie case is "de minimis"; only "minimal" proof of

D. Murphy, Equal Theories of Liability? Pay Disparity Claims Under the Equal Pay Act and Title VII of the Civil Rights Act, N.Y. L.J. (Feb. 21, 2020), https://www.law.com/newyorklawjournal/ 2020/02/21/equal-theories-of-liability-pay-disparity-claims-under-the-equal-pay-act-and-title-viiof-the-civil-rights-act/ [https://perma.cc/7NBA-GRBK].

144. Daniel S. Kleinberger, Donahue's Fils Aîné: Reflections on Wilkes and the Legitimate Rights of Selfish Ownership, 33 W. NEW ENG. L. REV. 405, 417-419 (2011) ("Wilkes does not cite McDonnell Douglas, but the parallel is inescapable.").

145. McDonnell Douglas, 411 U.S. at 802.

146. Wilkes, 353 N.E.2d at 662-63.

147. McDonnell Douglas, 411 U.S. at 802-03.

148. Wilkes, 353 N.E.2d at 663.

149. McDonnell Douglas, 411 U.S. at 804.

150. Wilkes, 353 N.E.2d at 663. 
IN CLOSELY HELD FIRMS

discrimination is necessary. ${ }^{151}$ The Second Circuit has noted that "“(i)n our diverse workplace, virtually any [employment] decision . . . will support a slew of prima facie cases of discrimination." 152 The initial burden under Wilkes is more demanding. That is, the Wilkes burden shifting is not triggered unless the plaintiff/partner demonstrates a reasonable expectation in investing that has been frustrated - the contours of a "freeze out." This is where a partner would need to show a reasonable expectation of employment or participation in management or fairness in share of profits. ${ }^{153}$ A partner's reasonable expectations are ascertained by examining the entire history of the parties' relationship. ${ }^{154}$ The inquiry is an objective one. ${ }^{155}$ The courts look to expectations as embodied in understandings, express or implied, among the parties. ${ }^{156}$ Thus, a partner's reasonable expectations in investing may be informed by contracts or informal agreements among the partners. ${ }^{157}$ In that connection, it may very well be that a partner can point to antidiscrimination statutes to establish a reasonable expectation that they would be treated fairly, regardless of sex.

Once a plaintiff/employee makes out the initial burden under McDonnell Douglas, the burden shifts to the defendant/employer to articulate a legitimate, non-discriminatory reason for its actions. ${ }^{158}$ This sounds remarkably similar to the burden shifting in Wilkes, which requires the majority owners to provide a legitimate business reason for their actions against the minority. ${ }^{159}$ What constitutes a "legitimate business purpose" is not explained in Wilkes, ${ }^{160}$ but, if the majority owners are acting in a discriminatory fashion based upon sex, they will likely be hard-pressed to establish a legitimate purpose for their actions. Indeed, cases where courts have found that majority owners lacked a legitimate business purpose for their actions have sounded a lot like what plaintiffs in discrimination cases claim - they were treated unfairly even though they performed their responsibilities competently and had the best interests of the business in mind. ${ }^{161}$

Finally, under Title VII, if the defendant/employer presents non-

151. Denny Chin \& Jodi Golinsky, Employment Discrimination: Moving Beyond McDonnell Douglas: A Simplified Method for Assessing Evidence in Discrimination Cases, 64 BROOK. L. REv. 659, 664 (1998).

152. Id. (quoting Fisher v. Vassar Coll., 114 F.3d 1332, 1337 (2d Cir. 1997)).

153. Meiselman v. Meiselman, 307 S.E.2d 551, 563-64 (N.C. 1983).

154. Id. at 563 .

155. Id.

156. Id.

157. Id.

158. McDonnell Douglas Corp v. Green, 411 U.S. 792, 802 (1973).

159. Wilkes v. Springside Nursing Home, Inc., 353 N.E.2d 657, 663 (Mass. 1976).

160. See Benjamin Means, The Vacuity of Wilkes, 33 W. New Eng. L. Rev. 433, 445 (2011).

161. See Keating v. Keating, No. 00748, 2003 WL 23213143, at*16 (Mass. Super. Oct. 3, 2003) ("To the contrary, Junior routinely carried out his responsibilities at Alder in a competent manner, with the best interests of the corporation in mind."). 
discriminatory reasons for its actions, the burden shifts back to the plaintiff/employee to demonstrate that the employer's reason is merely a pretext for discrimination. ${ }^{162}$ This is often where the employer's intent plays a central role. In disparate treatment cases, a plaintiff must establish that the employer intentionally treated employees differently based on sex. ${ }^{163}$ Proof of intent to treat employees differently based on sex is not only difficult to establish, it has been criticized as inflexible for failing to address implicit bias and structural discrimination. ${ }^{164}$ Nevertheless, this is where the burden shifting under Wilkes is much less taxing on the plaintiff/owner. Where the majority owners show a legitimate business purpose for their actions, the burden shifts to the minority to show that there was a less harmful means to achieve the desired result. ${ }^{165}$ There is no requirement that the minority show that the majority intended to treat female partners different than male partners - or any other state of mind of the majority owners. The minority owner must simply show that there was a less harmful way of achieving the desired result the majority have pointed to in justifying their actions. $^{166}$

This difference is significant. For example, if Straka were pursuing a disparate treatment claim, she would have to establish that her partners decided to provide her with comparatively insufficient support staff, at least in part, because she is a woman. ${ }^{167}$ Under the Wilkes analysis, as an owner, Straka would simply need to show that they could have shared the support staff more equitably among partners. There need not be any showing of an intent to discriminate, or even that the decisions were made based upon sex.

2. Harassment and Oppression Doctrine.-In addition to disparate treatment, harassment is a form of employment discrimination under Title VII. Harassment is "unwelcome conduct" that is based on sex (including pregnancy). ${ }^{168}$ "Harassment becomes unlawful where 1) enduring the offensive conduct becomes a condition of continued employment, or 2) the conduct is severe or pervasive enough to create a work environment that a reasonable person would consider

162. McDonnell Douglas, 411 U.S. at 804.

163. See, e.g., Bostock v. Clayton Cty., 140 S. Ct. 1731, 1740 (2020) (in "disparate treatment" cases, "the difference in treatment based on sex must be intentional" (citing Watson v. Fort Worth Bank \& Tr., 487 U.S. 977, 986 (1988))); see also Ricci v. DeStefano, 557 U.S. 557, 577 (2009).

164. Leora F. Eisenstadt \& Jeffrey R. Boles, Intent and Liability in Employment Discrimination, 53 Aм. Bus. L.J. 607, 608-09 (2016).

165. Wilkes v. Springside Nursing Home, Inc., 353 N.E.2d 657, 663 (Mass. 1976).

166. Id.

167. Bostock, 140 S. Ct. at 1741 ('It doesn't matter if other factors besides the plaintiff's sex contributed to the decision. And it doesn't matter if the employer treated women as a group the same when compared to men as a group. If the employer intentionally relies in part on an individual employee's sex when deciding to discharge the employee - put differently, if changing the employee's sex would have yielded a different choice by the employer - a statutory violation has occurred.").

168. Harassment, U.S. EQUAL EMP. OPPORTUNITY COMM'N, https://www.eeoc.gov/harassment (last visited Oct. 1, 2020) [https://perma.cc/5UTG-3YC3]. 
IN CLOSELY HELD FIRMS

intimidating, hostile, or abusive." 169 The second category, referred to as a "hostile work environment" claim, looks to whether the conduct would be offensive to reasonable people. ${ }^{170}$ "Offensive conduct may include, but is not limited to, offensive jokes, slurs, epithets or name calling, physical assaults or threats, intimidation, ridicule or mockery, insults or put-downs, offensive objects or pictures, and interference with work performance." ${ }^{\prime 11}$

Straka claimed that she was subject to unsolicited and demeaning behavior and was not treated with equal dignity and respect as the male owners. ${ }^{172}$ Given the body of anti-harassment laws and the shifting expectations in light of the \#MeToo Movement, there is a viable argument that she reasonably expected that she would not be harassed at work. In Straka's case, the demeaning cartoon and jokes were evidently gendered. ${ }^{173}$ Were the firm to argue that these unpleasant exchanges were not based on sex, the hostility alone, without tying it to gender discrimination, should be enough to establish oppression. After all, one would hope that an owner, regardless of gender, reasonably expects an environment free of targeted hostility. ${ }^{174}$

3. Application of Oppression Doctrine.-Campbell v. Chadbourne \& Parke $L L P$ provides a context to explore how oppression doctrine may provide an alternative to employment discrimination claims. ${ }^{175}$ There, Campbell, a partner in an international law firm, brought a putative class action against the firm, claiming discrimination against female partners in terms of compensation and involvement in management. ${ }^{176}$ She asserted claims under Title VII and the EPA, among other state law claims. ${ }^{177}$ A central issue early in the litigation was whether Campbell and the putative class of female partners were "employees" of the firm. ${ }^{178}$ It was an issue that the court declined to determine as a matter of law on summary judgment. ${ }^{179}$ If Campbell had, instead, fashioned the claim as one for oppression, the litigation would have looked much different. In the first instance, her position would have looked like that of Straka, arguing that a reasonable

169. Id.; see also Meritor Sav. Bank, FSB v. Vinson, 477 U.S. 57, 64-65 (1986); Rudow v. New York City Comm'n on Human Rights, 474 N.Y.S.2d 1005, 1010-13 (Sup. Ct. 1984), aff'd, 487 N.Y.S.2d 453 (App. Div. 1985).

170. Harassment, supra note 168.

171. Id.

172. Straka v. Arcara Zucarelli Lenda \& Assocs. CPAs, P.C., 92 N.Y.S.3d 567, 570-71 (Sup. Ct. 2019).

173. Id. at 571 .

174. Even if not, targeted hostility arguably makes carrying out the business no longer reasonably practicable, which is another common ground for dissolution of a business entity.

175. Campbell v. Chadbourne \& Parke LLP, No. 16-CV-6832 (JPO), 2017 WL 2589389 (S.D.N.Y. June 14, 2017).

176. Id. at $* 1-3$.

177. Id. at $* 1$.

178. Id. at $* 1-4$.

179. Id. at $* 4$. 
expectation of becoming a partner was that she would be treated fairly in terms of management voice and compensation, and this expectation was frustrated by an all-male management committee that did not pay her according to her production and did not give female partners meaningful say in management of the firm. Once she established that, the burden would be on the firm to establish a legitimate business reason for not compensating her according to production. The intent of the firm and the management committee, and whether their decisions were made on the basis of sex, would not be a necessary part of the analysis. Although, like Straka, Campbell certainly could choose to discuss the unfair treatment in gender-based terms.

Campbell sought declaratory and injunctive relief to redress the firm's practices, and also sought monetary relief in the form of, among other things, back pay, front pay, and compensatory damages. ${ }^{180}$ These are all available remedies under an oppression analysis, where the goal is to restore the partner's reasonable expectations. ${ }^{181}$ In the case, Campbell claimed that, in retaliation for raising the issues, she had been "secretly terminat[ed]," with her salary significantly decreased and six months to find another firm. ${ }^{182}$ In this connection, it is worth noting that her oppression claims would likely need to be framed in fiduciary terms, rather than statutory terms. The alleged "secret terminat[ion]"183 would also be part of the claim for breach of fiduciary duty. Campbell would not proceed under a statute first and foremost because the firm was organized as a limited liability partnership. But, further, had it been organized as a corporation, she would need to be a shareholder to petition for dissolution under the statute (and, in New York, there is a threshold of $20 \%$ or more of ownership to bring the petition).$^{184}$

Another context to consider the oppression doctrine is Baskett v. Autonomous Research $L L P .{ }^{185}$ Plaintiff Erin Baskett joined a London-based financial research firm as a partner to launch a United States office in New York City. ${ }^{186}$ In launching the New York office, among other things, Baskett set up a compliance monitoring structure for the firm, hired staff and ensured that the firm was fully compliant with applicable regulatory standards. ${ }^{187}$ Despite these significant contributions to the firm, among other claims, Baskett alleged that she received lower pay than her comparable male colleagues and was penalized for raising the issue. ${ }^{188}$ She brought discrimination and retaliation claims against the firm and its

180. Id. at $* 1$.

181. See supra notes $124-26$ and accompanying text.

182. Class Action Complaint, Campbell v. Chadbourne \& Parke LLP, No. 1:16-cv-06832, 2016 WL 4547501 ๆๆ 79-80 (S.D.N.Y. Aug. 31, 2016).

183. See id.

184. N.Y. Bus. Corp. LAW § 1104-a(a) (McKinney 2020).

185. Baskett v. Autonomous Research LLP, No. 17-CV-9237 (VSB), 2018 WL 4757962, at

*1 (S.D.N.Y. Sept. 28, 2018).

186. Id.

187. Id. at $* 1-2$.

188. Id. at $* 2$. 
leadership under the EPA, Title VII, and local anti-discrimination laws. ${ }^{189}$ The firm moved for summary judgment, claiming that Baskett was a partner and, thus, not an employee under Clackamas. ${ }^{190}$ The court declined to grant summary judgment on the issue of whether Baskett was an employee. ${ }^{191}$ While her claims survived a pre-discovery motion for summary judgment, in light of the threshold issue, and the court's denial of the motion "without prejudice to renewal following discovery relating to the Clackamas factors," the longevity of those claims in the litigation would proceed with uncertainty. ${ }^{192}$

If, instead, Baskett's claims were framed as a breach of fiduciary duty based on minority oppression, she may have fared better. She could have argued that she had a reasonable expectation in becoming a partner that she would be fairly compensated in relation to her contributions to the firm, and that expectation was frustrated. This would put the burden on the firm leadership to show a legitimate business purpose in undercompensating her relative to her contributions. ${ }^{193}$ Note that Baskett could frame the claim in gender-based terms, but she could also state the claim without reference to sex discrimination, because minority oppression doctrine would simply ask whether she was treated unfairly by the majority. ${ }^{194}$ Baskett would not need to prove that the firm leadership made the decision to pay her less than male colleagues, at least in part, because she was female.

4. Remedies.-As a fiduciary claim, the remedy for oppression is to restore the partner's reasonable expectations - whether it be to require that they be included in management decisions or be compensated fairly. ${ }^{195}$ The statutes, while framed as a petition for dissolution, often allow for broad equitable relief, including prohibition of continuing acts of 'oppressive' conduct, which may include reducing compensation for some and increasing it for others. ${ }^{196}$ Thus, oppression doctrine can provide the same relief as an employment discrimination case, such as backpay, front pay, or reinstatement. But oppression doctrine also allows for a wider range of potential remedies, and the statutory remedy gives quite a bit of leverage to a minority owner who is threatening dissolution of the firm.

\section{B. The Pitfalls of Oppression Doctrine}

Oppression may fill a doctrinal gap in employment law, but its applicability may be limited, and its aim is not to address gender-based discrimination.

189. Id. at $* 1$.

190. Id. at $* 5-6$.

191. Id. at *6.

192. Id.

193. Wilkes v. Springside Nursing Home, Inc., 353 N.E.2d 657, 663 (Mass. 1976).

194. In re Kemp \& Beatley, Inc., 473 N.E.2d 1173, 1179 (N.Y. 1984).

195. Brodie v. Jordan, 857 N.E.2d 1076, 1080 (Mass. 2006) (quoting Zimmerman v. Bogoff, 524 N.E.2d 849, 855 (Mass. 1988)).

196. See Baker v. Commercial Body Builders, Inc., 507 P.2d 387, 395-96 (Or. 1973); Brodie, 857 N.E.2d at 1080; see also supra note 105 and accompanying text. 
1. Limited Applicability.-First, as noted above, in many but not all states, a statutory claim for oppression is available for closely held corporations and LLCs, not limited partnerships or limited liability partnerships. ${ }^{197}$ Further, some, though certainly not all, corporate statutes have limited the right to petition the court to owners holding a certain threshold of interest. ${ }^{198}$ This, of course, does not foreclose the possibility of an oppression claim sounding in breach of fiduciary duty, unless there is a contract limiting these avenues. That is, because these business entities are creatures of contract, it is likely that an arbitration clause or other dispute resolution mechanism is in the shareholder, partnership, or LLC operating agreement, and that clause forecloses the right of the owner to bring the claims in court. ${ }^{199}$ While some states have moved to ban mandatory arbitration of discrimination claims, these statutes apply to employment contracts, not shareholder, partnership, or LLC operating agreements. ${ }^{200}$ Nevertheless, there may be reason, grounded in basic contract doctrine, for a court to refuse to enforce the dispute resolution clause in the firm's partnership agreement. For example, a Winston Strawn partner who brought gender discrimination claims against the law firm was able to obtain a ruling that the arbitration clause in the firm's partnership agreement was unconscionable and unenforceable. ${ }^{201}$

Further, to the extent that the oppression analysis is framed in fiduciary terms, there is a growing body of law that allows partners to restrict or entirely eliminate fiduciary duties to each other. ${ }^{202}$ It may be that a shareholder, partnership, or LLC operating agreement restricts or eliminates fiduciary obligations, which, in turn, affects the viability of a common law claim for oppression. Further, if an LLC operating agreement waives the right of members to seek judicial dissolution, it may serve to foreclose a statutory claim for oppression. ${ }^{203}$

Assuming the duties are not foreclosed or constrained by contract, and whether the oppression claim proceeds as a matter of common law fiduciary duty or statute, the owner will need to establish a reasonable expectation that was

197. See supra notes 128-34 and accompanying text.

198. See, e.g., N.Y. Bus. Corp. LAw § 1104-a(a) (McKinney 2020).

199. See B\&S MS Holdings, LLC v. Landrum, 302 So. 3d 605, 612 (Miss. 2020) (holding that LLC operating agreement can provide for mandatory arbitration of claim for judicial dissolution).

200. See N.Y. C.P.L.R. 7515 (McKinney 2020) (clauses in employment contracts that require arbitration of discrimination claims are unenforceable).

201. See Ramos v. Super. Ct., 239 Cal. Rptr. 3d 679 (Ct. App. 2018), modified, No. A153390, 2018 Cal. App. LEXIS 1090 (Ct. App. Nov. 28, 2018), rev. denied, No. S253014, 2019 Cal. LEXIS 981, cert. denied sub nom. Winston \& Strawn LLP v. Ramos, 140 S. Ct. 108 (2019); see also Marcia Coyle, Ex-Winston Partner, Suing Firm, Asks Justices to Uphold a Ruling Against Arbitration, NAT'L L.J., (July 31, 2019), https://www.law.com/nationallawjournal/ 2019/07/31/exwinston-partner-suing-firm-asks-justices-to-uphold-a-ruling-against-arbitration/ [https://perma.cc/MK9D-MQPL].

202. See Del. Code AnN. tit. 6, § 18-1101 (2019-2020) (LLC members may restrict or eliminate fiduciary duties).

203. See B\&S MS Holdings, LLC, 302 So. $3 \mathrm{~d}$ at $611-12$ (LLC member that owned $51 \%$ interest waived the right to seek judicial dissolution). 
frustrated. ${ }^{204}$ If the owner is claiming that continued employment was a reasonable expectation, this will require the owner to overcome the employmentat-will doctrine, which states just the opposite - that employment may be terminated at any time. The fiduciary duty of loyalty owed to an owner does not necessarily provide the owner with a reasonable expectation of continued employment. Indeed, the owner must establish that a reasonable expectation was that the return on investment was continued employment. ${ }^{205}$ Again, any shareholder or partnership agreement will play a role in the analysis, especially if it affirms or disaffirms or remains silent as to its effect on the default rule of atwill employment. ${ }^{206}$ An agreement that disaffirms at-will employment would provide solid evidence that the owner reasonably expected continued employment as a return on investment. ${ }^{207}$

Further, oppression doctrine protects owners and, therefore, is only a useful tool if the person suffering discrimination is, indeed, an owner. The doctrine is not going to apply, for example, to an associate that gets denied partnership. In that instance, however, oppression doctrine should not be needed to fill in any gaps, because employment discrimination statutes should apply.

2. Oppression Doctrine is Not Designed to Address Gender-Based Discrimination.-A larger point here is that oppression doctrine is not designed to address gender-based discrimination against owners. In any given case, it may seem an individual advantage that owners need not frame oppression claims in gender-based terms and may still be able to obtain the same relief they would under Title VII or the EPA. However, filling an employment law gap using corporate oppression doctrine does not serve the broader goals of combatting gender discrimination in the workplace. The purpose of oppression doctrine is to address the vulnerability of the minority owner that lacks exit from a closely held company. ${ }^{208}$ While the doctrine is broadly concerned with fair treatment and lack of exit for minority owners in closely held firms, it is not intended to address the specific vulnerability to discrimination based upon sex and is not necessarily equipped to do the heavy lifting of the calls for broader societal change. Substantively, unlike the oppression doctrine, an express goal of Title VII is to combat sex discrimination. ${ }^{209}$ Procedurally, an oppression claim is more likely to be brought on an individual basis. By contrast, a Title VII claim might be fashioned as a class action, which aims to achieve broader organizational

204. Moll, B.C., supra note 108, at 1001-02.

205. Merola v. Exergen Corp., 668 N.E.2d 351, 355 (Mass. 1996) ("Not every discharge of an at-will employee of a close corporation who happens to own stock in the corporation gives rise to a successful breach of fiduciary duty claim.").

206. See Gallagher v. Lambert, 549 N.E.2d 136, 138 (N.Y. 1989) (employment at-will applied and shareholder buyback agreement did not provide reasonable expectation of continued employment).

207. Moll, ILL., supra note 88, at 555.

208. See supra notes 56-63 and accompanying text.

209. See 42 U.S.C. $\S \S 2000$ e to -17 (2019). 
change. ${ }^{210}$

\section{CONCLUSION}

While existing employment laws do not ordinarily protect owners (partners, shareholders, LLC members) from discrimination, corporate oppression doctrine may provide an avenue of relief. Female owners who claim that they have been treated unfairly based upon gender-whether it is exclusion from meaningful participation in management or unfair distribution of profits - may be able to raise those claims under closely held business law doctrine. This avenue of relief may provide a remedy in individual cases where employment laws do not apply to owners, and the claims need not be framed in gender-based terms to proceed. However, without framing the claim in gender-based terms, the discriminatory aspect of the unfair treatment is not acknowledged and vindicated, and the broader goals of workplace equality are not advanced. While oppression doctrine may be promising in some individual cases, it is not a substitute for serious consideration of amending existing statutes to combat discrimination more widely than the narrow (and waning) construct of who is an "employee." Surely, a more expansive definition of the term "employee" would better serve the "broad remedial goals" of anti-discrimination laws. ${ }^{211}$ Indeed, the rising tide would lift all boats, and broader protections under anti-discrimination laws would not only benefit owners, it would likewise serve to protect independent contractors, who also do not fall within the narrow construct of "employee." 12

210. Indeed, Campbell was fashioned as a class action. Campbell v. Chadbourne \& Parke LLP, No. 16-CV-6832 (JPO), 2017 WL 2589389, at*1 (S.D.N.Y. June 14, 2017).

211. See Stephanie M. Greene \& Christine Neylon O'Brien, Partners and Shareholders as Covered Employees Under Federal Antidiscrimination Acts, 40 AM. Bus. L.J. 781, 791 (2003). (before Clackamas was decided, noting that "parties argued, and some courts agreed, that an expansive definition of the 'term' employee should be adopted to accomplish the broad remedial goals of antidiscrimination laws").

212. See Richard R. Carlson, Why the Law Still Can't Tell an Employee When It Sees One and How It Ought to Stop Trying, 22 Berkeley J. EMP. \& LAB. L. 295, 367 (2001). 